\title{
Do Demographic Variables Make a Difference in Entrepreneurial Leadership Style?
}

\section{Case Study Amongst Micro and Small in Creative Economy Entrepreneurs in Jakarta, Indonesia}

\author{
Aristo Surya Gunawan, Atma Jaya Catholic University, Indonesia \\ Ati Cahayani, Atma Jaya Catholic University, Indonesia
}

\begin{abstract}
Industry 4.0 brings a challenge in terms of labor reduction. However, there is an opportunity in job creation for the creative industry/economy. The creative economy in Indonesia shows an increasing contribution to the Indonesian economy in recent years, and it is also predicted to continue increasing in the future. Leadership for the entrepreneur is needed to make their business entity (micro, small, medium enterprises) to survive and succeed. This research aims to find out whether there is a difference in entrepreneurial leadership style with four demographic variables (i.e., gender, age, education level, and marital status).
\end{abstract}

\section{KEYWORDS}

Creative Economy, Demographic Variables, Entrepreneurial Leadership

\section{A. INTRODUCTION}

The emerge of industry 4.0 bring new hope in accelerating economic growth. However, industry 4.0 also brings a challenge in job opportunity creation. Based on SWOT analysis by Digital Transformation Monitor (2017), the weakness of industry 4.0 is potential deployment at "shop-floor" level workers. This threat of the presence of industry 4.0 in reducing labor does not apply to all industry types. An industry that is not too affected in labor reducing is the creative industry because it is based on creativity, art, culture, and innovation. Bakhshi et al. (2015) said that creative occupations are more future-proof to computerization. Around $86 \%$ of workers in US and UK are found to be at low or no risk of automation since they are in a highly creative category.

In Indonesia, the creative economy shows an increasingly contribution to the Indonesian economy in recent years. Triawan Munaf, Chief of Indonesian Creative Economy Agency in Saputri (2018) said the GDP of the creative economy shows increasing figures from IDR 992 Trillion in 2016 to IDR 1,100 Trillion in 2018. Furthermore, Mr.Munaf told that the creative economy contributes $7.44 \%$ to the Indonesian economy and also contributes $13.77 \%$ (or USD 20 million) from total Indonesian exports in 2016. These numbers are predicted to be increasing continuously.

Strong entrepreneurs are needed to develop creative economy businesses, especially at Micro, Small, and Medium Enterprises (MSMEs). To survive and even success, MSMEs require a strong 
personality from the entrepreneur itself as a leader. Leadership for an entrepreneur is a vital capital to align all resources in the business. Without strong leadership, there is no big vision that can build a big business. Creativity, innovation, and the ability to seek opportunities are the entrepreneurial characteristics necessary for the creation of MSME, particularly in the creative economy.

\section{B. LITERATURE REVIEW}

\section{Concept of Leadership}

Leadership theory approaches are dividing into two major groups, which are traditional and modern theories (described in table 1). Esmer and Dayi (2016) define leadership as the process of influencing employees of an organization to achieve organizational goals. Although there are many definitions of leadership, there is a red line on leadership, which is the process of influencing employees and guiding them in the right direction.

Table 1. Leadership Theory

\begin{tabular}{|l|l|}
\hline Theory & Summary \\
\hline Traditional Leadership Theory & \\
\hline $\begin{array}{l}\text { Trait approach (Between 1910 - } \\
1940)\end{array}$ & Explained general characteristics of the leader \\
\hline $\begin{array}{l}\text { Behavioral approach (Between 1940 } \\
-1960)\end{array}$ & Described behaviors of the leader \\
\hline $\begin{array}{l}\text { Contingency approach (Between } \\
1960-1980)\end{array}$ & $\begin{array}{l}\text { Leadership behavior should not be specific, but it varies } \\
\text { depends on the situation. }\end{array}$ \\
\hline $\begin{array}{l}\text { Modern Leadership Theory (1980 } \\
\text { till today) }\end{array}$ & $\begin{array}{l}\text { Varies depending on the direction of change of the society, } \\
\text { i.e., authentic leadership, transformational leadership, } \\
\text { spiritual leadership, charismatic leadership, visionary } \\
\text { leadership, cultural leadership, servant leadership, quantum } \\
\text { leadership, entrepreneurial leadership. }\end{array}$ \\
\hline \\
\hline
\end{tabular}

\section{Concept of Entrepreneurial Leadership}

Entrepreneurial leadership definition according several sources can be seen in table 2. The success of businesses depends on effective leadership skills. One of the effective leadership skills is entrepreneurial leadership. Corbin in Sutrisno (2013) said that with an entrepreneurial leadership style, a leader enables to delegate, to build employees behaving responsibly, to make and determine decisions, and to work independently. Entrepreneurial leadership concept, according to Thornberry (2006), is leadership in the context of an entrepreneur as a leader in their business organization.

\section{METHODOLOGY}

This article is a descriptive study using secondary data from Gunawan et al. (2016) research. In that research, quantitative data was gathered through questionnaires. The population is the creative industry/business ${ }^{1}$ entrepreneurs in Jakarta and questionnaires were distributed to 150 respondents by using purposive, quota, and accidental sampling. Purposive sampling was used to select the respondents with a minimum of two employees. Quota sampling was used to select respondents in 5 areas in Jakarta (north, south, east, west, and central) with 30 respondents in each area. Accidental sampling was used to select the respondents that were willing and available to fill the questionnaires. 
Table 2. Entrepreneurial Leadership Theory

\begin{tabular}{|l|l|}
\hline \multicolumn{1}{|c|}{ Sources } & \multicolumn{1}{c|}{ Entrepreneurial Leadership Definition } \\
\hline Alvarez and Barney (2002) & $\begin{array}{l}\text { a type of leadership that consists of actions towards } \\
\text { establishment of business at the individual level, actions } \\
\text { towards following the innovations at the organizational level } \\
\text { and actions towards benefiting from the opportunities that are } \\
\text { distinguished at the market level }\end{array}$ \\
\hline Kuru in Esmer and Dayi (2017) & $\begin{array}{l}\text { a concept appeared by blending the leadership potential with } \\
\text { the entrepreneurial spirit }\end{array}$ \\
\hline Renko et al. (2015) & $\begin{array}{l}\text { as affecting and directing the performance of employees } \\
\text { toward the achievement of organizational objectives that } \\
\text { involve recognizing and exploiting entrepreneurial } \\
\text { opportunities }\end{array}$ \\
\hline Darling et al. (2007) & $\begin{array}{l}\text { a process of connecting innovation and the ability to seize } \\
\text { opportunities. }\end{array}$ \\
\hline Goosen (2007) & $\begin{array}{l}\text { the process of creating and developing an entrepreneurial } \\
\text { culture through brilliant new initiatives. }\end{array}$ \\
\hline
\end{tabular}

Based on mean score data from Gunawan et al. (2016), this article will compare mean independent sample t-test for (general) entrepreneurial leadership mean score using four demographic predictors which are: gender, age, education level, and marital status. Entrepreneurial leadership variable derived from Thornberry Entrepreneurial Leadership Questionnaires (ELQ). Before performing compare mean independent sample t-test, we perform a normality test using one sample Kolmogorof-Smirnov.

\section{FINDINGS}

Respondents profile described below in table 3 , and normality test showed in table 4. One sample $\mathrm{K}-\mathrm{S}$ test asymp.sig value is 0.245 which is bigger than 0.05 means entrepreneurial leadership mean score data is normal

From table 5, all demographic variables show F-test significance value is bigger than 0.05 . Therefore, we should look to the Equal Variance Assumed column rather than Equal Variance Not Assumed. The t-test significance value of equal variance assumed for education, age, and status is bigger than 0.05. It means that there is no difference in terms of entrepreneurial leadership for these three demographic variables. However, the t-test significance value of equal variance assumed for gender is smaller than 0.05 . It means that there is a difference in terms of entrepreneurial leadership for gender.

Leadership skill commonly said as an art. It is a gift or talent for some people. Therefore it is similar to the result above, that entrepreneurial leadership is not different in terms of educational level, age, or status. We cannot say that the more age or education will cause better leadership skills or vice versa. Also, we cannot say that married people are better in leadership skills than single ones and vice versa. However, in terms of gender, it is more likely that the difference is because of nature gender typical stereotyping. This typical gender nature differentiation proves to cause differentiation in their leadership style as well. 
Table 3. Respondents profile

\begin{tabular}{|c|c|c|c|c|}
\hline \multicolumn{1}{|c|}{ Demographic Variables } & Frequency & Percentage & $\begin{array}{c}\text { Mean } \\
\text { Score }\end{array}$ & $\begin{array}{c}\text { Std } \\
\text { Deviation }\end{array}$ \\
\hline Gender & & & & \\
\hline$\bullet \quad$ Male & 65 & 43 & 3.73 & 0.42 \\
\hline$\bullet \quad$ Female & 85 & 57 & 3.89 & 0.46 \\
\hline Education & & & & \\
\hline$\bullet \quad$ Non-Bachelor & 78 & 52 & 3.82 & 0.48 \\
\hline$\bullet \quad$ Bachelor & 72 & 48 & 3.83 & 0.41 \\
\hline Age $\quad$ Max 30 years & 60 & 40 & 3.87 & 0.49 \\
\hline$\bullet \quad$ Above 30 years & 90 & 60 & 3.79 & 0.41 \\
\hline Status $\quad$ Married & 92 & & & \\
\hline$\bullet \quad$ Unmarried & 58 & 39 & 3.82 & 0.43 \\
\hline$\quad$ & & & \\
\hline
\end{tabular}

Table 4. Normality Test

One-Sample Kolmogorov-Smirnov Test

\begin{tabular}{|c|c|c|}
\hline & & GEL \\
\hline $\mathrm{N}$ & & 150 \\
\hline \multirow[t]{2}{*}{ Normal Parameters ${ }^{\mathrm{a}}$} & Mean & 3.8260 \\
\hline & Std. Deviation & .44908 \\
\hline \multirow[t]{3}{*}{ Most Extreme Differences } & Absolute & .084 \\
\hline & Positive & .048 \\
\hline & Negative & -.084 \\
\hline Kolmogorov-Smirnov Z & & 1.024 \\
\hline Asymp. Sig. (2-tailed) & & .245 \\
\hline
\end{tabular}

Table 5. Summary of Result Compare Means Independent Sample t-test Using SPSS

\begin{tabular}{|l|c|c|}
\hline \multicolumn{1}{|c|}{ Demographic Variables } & $\begin{array}{c}\text { Levane Test Equality of } \\
\text { Variance (F test sig) }\end{array}$ & $\begin{array}{c}\text { Equal Variance Assumed (t } \\
\text { test sig) }\end{array}$ \\
\hline Gender & 0.123 & $\mathbf{0 . 0 2 5}$ \\
\hline Education & 0.098 & 0.963 \\
\hline Age & 0.106 & 0.311 \\
\hline Status & 0.307 & 0.797 \\
\hline
\end{tabular}




\section{E. CONCLUSION AND RECOMMENDATION}

From the explanation above, we can see that entrepreneurial leadership among respondents is no different in terms of demographic variables (age, education level, and marital status), except for gender. Since this article only performing quantitative analysis, it cannot explain further and deeper why or how gender can make a difference in entrepreneurial leadership style. Perhaps a qualitative study can give us more explanation about this gender caused distinction. 


\section{REFERENCES}

Alvarez, S. A., \& Barney, J. R. (2002). Resource-based theory and the entrepreneurial firm. In M. A. Hitt, R. D. Ireland, S. M. Camp, \& D. L. Sexton (Eds.), Strategic Entrepreneurship: Creating a New Mindset. Blackwell.

Bakhshi, Frey, \& Osborne. (2015). Creativity vs. Robots: The Creative Economy and The Future of Employment. Retrieved from https://media.nesta.org.uk/documents/creativity_vs._robots_wv.pdf

Darling, J., Keeffe, M., \& Ross, J. (2007). Entrepreneurial Leadership Strategies and Values: Keys to Operational Excellence. Journal of Small Business and Entrepreneurship, 16(2), 108-109. doi:10.1080/08276331.2007.1 0593385

Digital Transformation Monitor. (2017). Germany: Industry 4.0. Retrieved from https://ec.europa.eu/growth/ tools-databases/dem/monitor/sites/default/files/DTM_Industrie\%204.0.pdf

Esmer, Y., \& Dayi, F. (2016). A New Paradigm In Management: Ethical Leadership. Akademik Bakis Uluslararasi Hakemli Sosyal Bilimler Dergisi, 57, 38-54.

Esmer, Y., \& Dayi, F. (2017). Entrepreneurial Leadership: A Theoretical Framework. Mehmet Akif Ersoy Universitesi. Iktisadi ve Idari Bilimler Fakultesi Dergisi, 4(2), 112-124.

Fernald, L. W. Jr, Solomon, G. T., \& Tarabishy, A. (2005). A New Paradigm: Entrepreneurial Leadership. Southern Business Review, 30(2), 1-10.

Goossen, R. J. (2007). Entrepreneurial Leaders: Reflection on Faith at Work. Trinity Western University Publishing Vancouver.

Gunawan, Cahayani, \& Wibowo. (2016). Review to the Entrepreneurial Leadership Amongst Creative Economy Entrepreneurs in Jakarta. Academic Press.

Renko, M., El Tarabishy, A., Carsrud, A. L., \& Brännback, M. (2015). Understanding and Measuring Entrepreneurial Leadership Style. Journal of Small Business Management, 53(1), 54-74. doi:10.1111/jsbm.12086

Saputri, K. (2018). Semakin Diminati, PDB Ekonomi Kreatif Capai Rp.1.100 Triliun. Retrieved from https:// www.bekraf.go.id/berita/page/8/semakin-diminati-pdb-ekonomi-kreatif-capai-rp1000-triliun

Sutrisno, R. P. (2013). Analisis Pengaruh Entrepreneurial Leadership dan Motivasi Terhadap Kinerja Karyawan PT. Karunia Lestari Xpresif (Tesis). School of Business Management Universitas Bina Nusantara. Retrieved from http://thesis.binus.ac.id/doc/Lain-lain/2013-1-00258-MN\%20WorkingPaper001.pdf

Thornberry, N. (2006). Lead Like an Entrepreneur. McGraw-Hill.

\section{ENDNOTE}

There are 16 subsectors of the creative economy that determined by the Indonesian Creative Economy Agency. They are application and game developer, architecture, product design, interior design, fashion, visual communication design, performing arts, film animation and video, photography, craftsmanship, music, publishing, advertising, fine arts, TV and Radio, Culinary.

Aristo Surya Gunawan holds a bachelor degree in accounting and a master degree in management. Since 2003 until now, he has been teaching Entrepreneurship in Business Administration Department Atma Jaya Catholic University of Indonesia. He has written several articles in international scientific journals and books. In addition to teaching he also has experience in business consulting.

Ati Cahayani holds a doctorate degree in education. Since 1998 has been a teaching in Human Resources, Organizational Theory, and Entrepreneurship in the Business Administration Department Atma Jaya Catholic University of Indonesia. She has written several books in Human Resources, Organizational Theory, and Culture as well as the Entrepreneurship books. She has also written several articles in scientific journals both internationally and nationally. In addition to teaching, she also a translator and editor of books that have been published by several publishers. 